\title{
Preference for drone brood cells by Varroa jacobsoni Oud in colonies of Apis mellifera carnica
}

\author{
S Fuchs \\ Institut für Bienenkunde (Polytechnische Gesellschaft), Fachbereich Biologie der \\ JW Goethe-Universität, Frankfurt am Main, D-6370 Oberursel, FRG
}

(Received 24 February 1989; accepted 20 February 1990)

\begin{abstract}
Summary - In colonies of A mellifera carnica infested with Varroa jacobsoni, the invasion of worker brood cells and drone brood cells by reproductive female mites was studied. In 68 choices between brood combs of both cell types, the infestation of mites per cell was, on average, 8.3 times higher in drone brood. This drone cell preference was not affected by the infestation level. It was more marked if drone brood was rare and it decreased towards the end of the drone rearing season.
\end{abstract}

Apis mellifera carnica / Varroa jacobsoni / host selection / drone brood / preference

\section{INTRODUCTION}

Preference of the parasitic mite Varroa jacobsoni for drone brood cells of its host Apis mellifera is very obvious and was noted by various authors (Grobov, 1977; Smirnov, 1979). Drone cell preference (DCP) is partly influenced by the properties of the brood cells. Larger cells contain higher numbers of mites (Message and Gonçalves, 1983). Cells protruding over the comb surface either naturally (de Jong and Morse, 1988) or induced by partly filling them with melted wax (de Ruijter, 1986; de Ruijter and Calis, 1988) were shown to contain increased numbers of Varroa mites. Rather than the shape of the cell, the time and construction effort needed for capping might be the relevant factor in determining the degree of mite infestation. In addition, stimuli from the larvae themselves are involved. Drone larva are preferred in vitro over worker larvae in choice experiments (Rosenkranz et al, 1984; Otten and Fuchs, 1989). Biotechnical control of varroatosis can be accomplished by removing sealed drone cells from the colonies (Ruttner et al, 1980; Schulz et al, 1983; Rosenkranz and Engels, 1985). The average number of female mites invading a brood cell was found to be 5.47 times higher in drone brood in Brazil (Issa and Gonçalves, 1984), 7.2 in Yugoslavia (Sulimanovic et al, 1982) and 8.6 times in Western Germany (Schulz, 1984). In the present study, the influence of the amount of brood cells, numbers of Varroa females entering cells, 
relative proportions of last instar drone and worker brood cells, and the season on female mite drone cell preference was investigated.

\section{METHODS}

The experiment (15 May-28 July 1987) used 26 Varroa infested hives; each hive consisted of 2 brood chambers separated by a queen excluder. Brood combs of the same age were produced by placing empty drone and worker combs into the upper chamber, which contained the queen. These were checked for eggs at intervals of 2-3 d. Drone and worker combs containing same-aged drone and worker larvae, respectively, were placed in the lower brood chamber.

From these combs, worker brood combs and drone brood combs containing 5th instar larvae shortly before capping were combined into pairs. In colonies containing a pair of combs ready for capping, no other brood of the same age was present. Two to $3 \mathrm{~d}$ after cell sealing, the combs were removed and deep-frozen. The numbers of capped cells were evaluated using a $(2 \times 2 \mathrm{~cm})$ grid. The numbers of Varroa were determined by washing the mites from the cells with a hand shower into a double sieve (Maul, 1984).

\section{RESULTS}

Cell capping of both drone and worker brood combs in any 1 pair of combs took place simultaneously in 68 pairs of combs. In most cases $(80.9 \%)$, the numbers of sealed worker cells exceeded that of drone cells. Table I gives the results of mite infestation for all pairs of combs. Infestation rates (Varroa/cell) varied widely in both brood types depending on the numbers of available cells and on the numbers of infesting Varroa. Drone cell preference (drone cell infestation rate/worker cell infestation rate) was highly variable between pairs of combs, but was in favour of drone cells in all but 1 case (mean: 8.33, min: 0.94, max: 30.6).

Drone cell preference was not influenced by the numbers of infesting mites nor by the total numbers of available cells, though with smaller proportions of drone cells in a pair of combs, drone cell preference was significantly higher (fig 1, regression: $\log (y)=-0.45 x+0.95, r=-0.336$, $P<0.01)$. In natural conditions, drone cells represent approximately $5-15 \%$ of the brood cells. In the 17 comb pairs within this range, the average drone cell preference was 12.07 ( $\min : 3.88$, $\max : 28.10$ ).

Table I. Invasion of brood cells by Varroa in a choice situation between a worker and a drone brood comb. Mean values and extremes (in parenthesis) of 68 pairs of combs. Infestation rate $=$ Varroa/cell; drone cell preference $=$ drone cell infestation rate/worker cell infestation rate.

\begin{tabular}{|c|c|c|c|}
\hline & Cells & Varroa & Infestation rate \\
\hline $\begin{array}{l}\text { Worker } \\
\text { combs }\end{array}$ & $\begin{array}{c}1091.0 \\
(23-3892)\end{array}$ & $\begin{array}{c}185.4 \\
(3-944)\end{array}$ & $\begin{array}{c}0.19 \\
(0.0068-1.086)\end{array}$ \\
\hline $\begin{array}{l}\text { Drone } \\
\text { combs }\end{array}$ & $\begin{array}{c}451.3 \\
(12-1550)\end{array}$ & $\begin{array}{c}383.0 \\
(4-2158)\end{array}$ & $\begin{array}{c}1.15 \\
(0.037-5.724)\end{array}$ \\
\hline $\begin{array}{l}\text { Proportion of drone } \\
\text { cells in pairs }(\%)\end{array}$ & \multicolumn{2}{|c|}{$32(0.31-95)$} & $\begin{array}{l}\text { Drone cell } \\
\text { preference }\end{array}$ \\
\hline $\begin{array}{l}\text { Proportion of Varroa } \\
\text { infesting drone cells } \\
\text { in pairs }(\%)\end{array}$ & \multicolumn{2}{|c|}{$65(8.1-99)$} & $\begin{array}{c}8.33 \\
(0.94-30.6)\end{array}$ \\
\hline
\end{tabular}




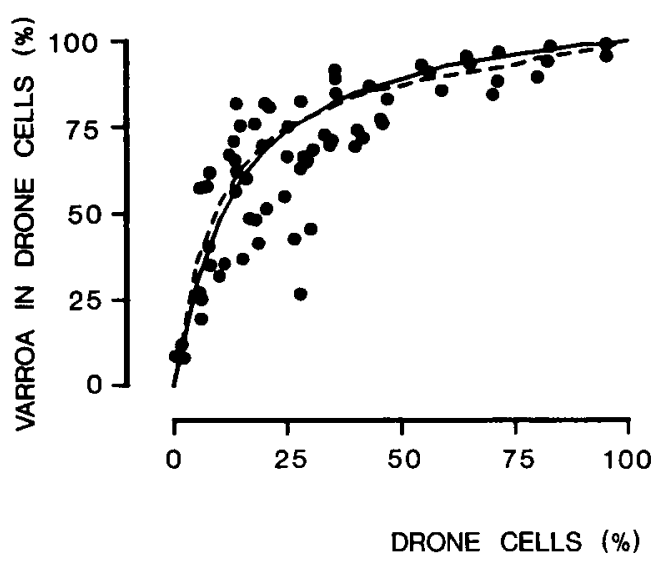

Fig 1. Preference of Varroa mites for drone cells in relation to the proportion of drone cells to worker cells (abscissa, \%) in a choice situation between a drone and a worker comb within a bee hive. Drone cell preference (ordinate): (Varroal worker cells)/(Varroa/drone cells). Each point represents a pair of combs.

A slight, though non-significant, decrease of drone cell preference during the period of the investigation is shown in figure 2 (Regression: $\log (y)=-0.00387 \cdot x$ $+0.98, r=-0.213)$. Drone cells were offered at lower proportions at the end of the investigation period. The decrease of drone cell preference with date is thus partly counteracted by higher preference with the decrease in the proportions of drone cells. The effect of these confounding variables on drone cell preference was examined by calculating partial correlations. This shows that drone cell preference decreases with $r=-0.316(P<0.05)$ when the effect of the proportion of drone cells is removed. If the effect of date is removed, the negative correlation between drone cell preference and proportion of drone cells is highly significant (partial correlation coefficient $r=-0.401, P<0.001$ ).

Figure 3 gives the distribution of the mites between the cell types calculated for

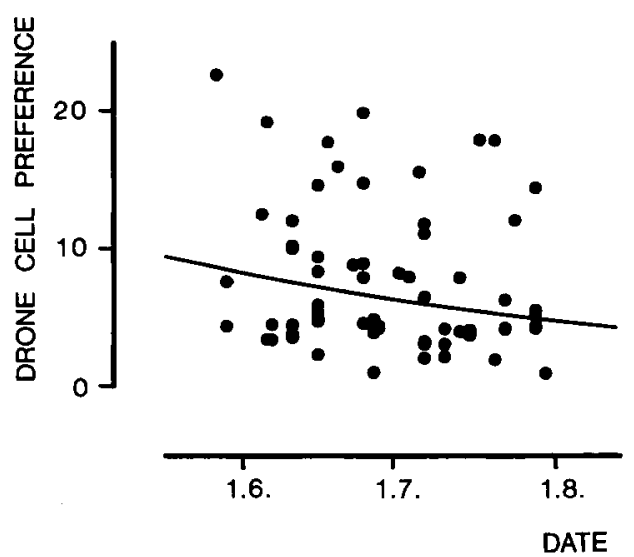

Fig 2. Preference of Varroa mites for drone cells in relation to the time of year (abscissa: date) in a choice situation between a drone and a worker comb within a bee hive. Drone cell preference (ordinate): (Varroa/worker cells)/(Varroa/drone cells). Each point represents a pair of combs.

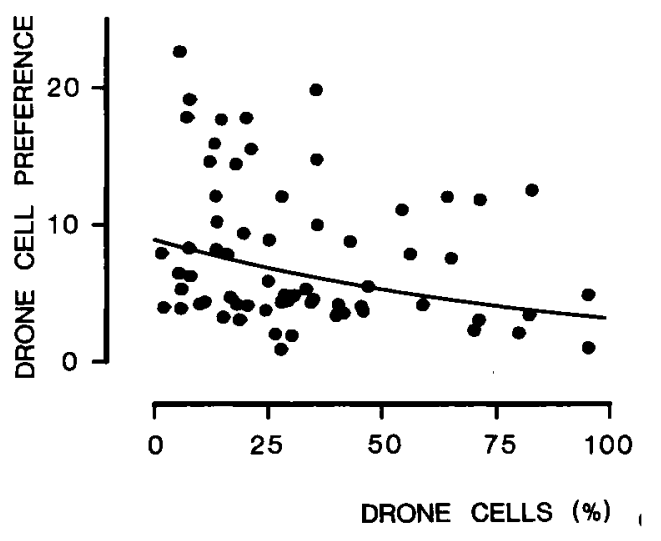

Fig 3. Percentage of Varroa infesting drone brood cells (ordinate) in relation to the percentage of drone brood cells (abscissa). Each point represents a pair of combs in a choice situation between a drone and a worker comb within a bee hive. Solid line: percentage in drone brood cells calculated for the mean DCP of 8.33. Dashed line: proportions calculated from DCP as given by the regression equation in figure 1 . 
the average drone cell preference of DCP $=8.33$ by the formula: \% Varroa in drone cells $=$ DCP.\% drone cells $\times 100 /$ (DCP.\% drone cells $+\%$ worker cells). With only $10 \%$ drone cells and $90 \%$ worker cells, the drone cells would harbour $48 \%$ of the Varroa. The observed values are higher at low drone cell proportions and lower at high drone cell proportions $(P<0.05,(2 \times 2)$ contingency test), which reflects the dependency of drone cell preference on drone cell ratio demonstrated above. This influence is shown by the curve using DCP values according to the regression equation in figure 1.

\section{DISCUSSION}

The mean 8.33-fold preference of drone cells to worker cells by Varroa mites is closely related to the value of $\mathbf{8 . 6}$ given by Schulz (1984), who compared 13 pairs of brood combs. A similar value (7.2) was reported by Sulimanovic et al (1982). Within a realistic range of drone cell proportions of $5-15 \%$, the drone cell preference value of 12.1 found in the present study is considerably higher. Though experimental conditions were as uniform as possible, the range of deviations was still very high. This conforms to earlier findings, which showed that the cell infestation behavior of Varroa is variable due to unknown factors (Fuchs, 1985, 1989).

A significant decrease in drone cell preference was found with date during the drone rearing season. This is in accordance with the results of Otten (1986) based on field samples and on in vitro choice tests of Varroa mites between drone and worker larvae. It is likely that the relative intensity of the attraction of the drone larvae decreases towards the end of the drone-production season, when they are nursed less intensively.
Drone cell preference clearly depended on the proportion of drone cells. It was high with small proportions of drone cells and decreased by about 1 half at high proportions of drone to worker cells. Apart from the possibility that smaller brood areas might attract relatively more mites than larger areas, these data support the findings of Otten (1986) and Otten and Fuchs (1989), that individual Varroae differ in their DCP. If so, Varroae of high DCP are restricted to fewer drone cells as these become rare.

DCP was not influenced by the number of infesting mites or the absolute number of available cells. Thus, the number of Varroae infesting a cell did not affect the infestation behavior. The average proportion of Varroae which gathers within drone combs was determined only by DCP and the relative proportion of drone cells. The data and the calculated curves show that, even with moderate proportions of drone cells, substantial numbers of mites will be found within drone combs. This emphasizes the efficacy of the removal of sealed drone brood combs as a means of Varroa control (Ruttner et al, 1980; Schulz et al, 1983; Rosenkranz and Engels, 1985).

\section{ACKNOWLEDGMENTS}

I thank M Ullmann for assisting with the colony routines, $M$ Kühnert and $D$ Wegener for help with mite counts, and $\mathrm{N}$ Koeniger for support and valuable discussions. This research was supported by Deutsche Forschungsgemeinschaft grant Ko-400/7-1.

Résumé - Préférence des cellules de couvain de mâles par Varroa jacobsoni Oud dans les colonies d'Apis mellifica L. L'acarien parasite Varroa jacobsoni préfère, pour se reproduire, les cellules de 
couvain de mâles à celles d'ouvrières. Dans ce choix, l'architecture de la cellule (de Ruijter, 1986; de Jong et Morse, 1988; de Ruijter et Calis, 1988) aussi bien que les larves elles-mêmes (Rosenkranz et al, 1984; Otten et Fuchs, 1989) sont déterminantes. Le degré de préférence a été estimé sur des échantillons de couvain provenant de colonies parasitées (Sulimanovic et al, 1982; Schulz, 1984; Issa et Gonçalves, 1984). Le présent travail a pour but de déterminer, en conditions contrôlées, les facteurs de cette préférence, en étudiant l'influence de la quantité de couvain, des proportions relatives des 2 types de cellules de couvain, du nombre d'acariens et de la saison. Des couples de rayons de couvain, comprenant un rayon de couvain de mâles et un rayon de couvain d'ouvrières de même âge, ont été constitués et placés dans des colonies parasitées du 15 mai au 28 juillet 1987. Au moment de l'introduction des rayons $\left(5^{\ominus}\right.$ stade larvaire, peu avant l'operculation), il n'y avait dans les colonies aucun autre couvain du même âge. Après l'operculation les surfaces de couvain ont été mesurées et le taux de parasitisme estimé par la méthode du lavage (Maul, 1984).

Les résultats portant sur 68 paires de cadres sont présentés dans le tableau I. Le rapport couvain de mâles/couvain d'ouvrières a varié très fortement, de même que le taux de parasitisme. La préférence pour les cellules de mâles (rapport varroas par cellule de mâle/varroas par cellule d'ouvrière) est de 8,3 en moyenne avec de très fortes variations individuelles (minimum 0,94; maximum 30,6). Ce chiffre concorde avec les valeurs trouvées par Schulz en $1984(8,6)$ et Sulimanovic et al en $1982(7,2)$. Il apparaît une préférence plus marquée quand la quantité de couvain de mâles diminue (fig 1). Lorsqu'il y a 5 à $15 \%$ de cellules de couvain de mâles (proportions rencontrées en conditions na- turelles), la préférence pour ces dernières est de 12,1. L'une des causes possibles pourrait être la préférence individuelle variable des acariens pour le couvain de mâles (Otten, 1986; Otten et Fuchs, 1989). De ce fait, lorsque la quantité de couvain de mâles est faible, les acariens se concentreraient dans celui-ci. Ni la quantité totale de couvain disponible, ni le nombre d'acariens n'ont eu d'influence sur la préférence pour les cellules de mâles. Celle-ci est par conséquent indépendante du taux de parasitisme des cellules. Elle est, par contre, atténuée vers la fin de l'expérience (fig 2). Ceci est à attribuer vraisemblablement à une attractivité réduite des larves de mâles recevant moins de soins en fin de saison. Les données montrent que, même lorsque le couvain de mâles est en faible proportion, on y trouve des quantités élevées d'acariens (fig 3). Cela fait ressortir l'intérêt du retrait des cadres de couvain de mâles operulé comme moyen de lutte contre Varroa (Ruttner et al, 1980; Schultz et al, 1983; Rosenkranz et Engels, 1985).

Apis mellifica carnica / Varroa jacobsoni / choix hôte / couvain mâle / préférence

\section{Zusammenfassung - Bevorzugung von Drohnenbrutzellen in Bienenvölkern von Apis mellifera carnica durch Varroa jacobsoni Oud. Die parasitische Milbe} Varroa jacobsoni bevorzugt für ihre Reproduktion Drohnenbrutzellen gegenüber Arbeiterinnenbrutzellen. Hierfür sind sowohl die Bauart der Zellen (De Jong und Morse, 1988; de Ruijter, 1986; de Ruijter und Calis, 1988) als auch die Larven selbst (Rosenkranz et al, 1984; Otten und Fuchs, 1989) bestimmend. Die Stärke dieser Präferenz ist wiederholt an Brutproben,aus befallenen Völkern abgeschätzt worden (Sulimanovic et al, 1982; Schulz, 1984; 
Issa und Goncalves, 1984). In der vorliegenden Arbeit sollte diese Präferenz unter kontrollierten Bedingungen bestimmt werden und hierbei eine mögliche Beeinflussung durch das Brutangebot, das Verhältnis beider Bruttypen, die Milbenanzahlen oder die Jahreszeit untersucht werden. Hierzu wurden im Zeitraum vom 15. Mai bis 28 . Juli 1987 jeweils Paare aus einer gleichalten Drohnenbrutwabe und einer Arbeiterinnenbrutwabe gebildet und in varroabefallene Völker eingestelit. Zum Zeitpunkt des Befalls (fünftes Larvenstadium kurz vor Zellverdeckelung) befand sich keine weitere gleichalte Brut in den Völkern. Nach Verdeckelung wurden die Brutflächen ausgemessen und der Varroabefall durch Auswaschen bestimmt (Maul, 1984). Die Ergebnisse aus 68 Wabenpaaren sind in Tabelle 1 aufgeführt. Das Verhältnis von Drohnenbrut zu Arbeiterinnenbrut varrierte sehr stark, ebenso der Befall mit Varroamilben. Die Bevorzugung von Drohnenzellen (Varroae pro Drohnenzelle/Varroae pro Arbeiterinnenzelle) betrug im Mittel 8,3 bei sehr stark schwankenden Einzelwerten (Minimum 0,94, Maximum 30,6). Dies entspricht den Angaben von Schulz (1984) mit 8,6 und Sulimanovic et al (1982) mit 7,2. Es zeigte sich eine deutlich höhere Präferenz bei abnehmendem Drohnenbrutangebot (Abb 1). Innerhalb eines natürlichen Anteils von 5 bis 15\% Drohnenbrutzellen war die Drohnenbrutpräferenz 12,1fach. Eine der möglichen Ursachen hierfür könnte eine unterschiedlich hohe Drohnenbrutpräferenz der einzelnen Milben sein (Otten, 1986; Otten und Fuchs, 1989). Hierdurch würden sich Milben hoher Präferenz bei nur geringem Drohnenbrutangebot in dieser konzentrieren. Das Brutangebot insgesamt oder die Anzahl der eindringenden Milben hatten keinen Einfluß auf die Drohnenbrutpräferenz. Diese ist damit vom Befallsgrad der Zellen unabhängig. Dagegen war sie gegen Ende des Versuchszeitraums verringert (Abb 2). Dies ist vermutlich auf eine verringerte Attraktivität der jahreszeitbedingt dann schlechter gepflegten Drohnenlarven zurückzuführen. Die Daten zeigen, daß bereits bei geringem Drohnenbrutangebot erhebliche Anteile der Milben in der Drohnenbrut anzutreffen sind (Abb 3). Dies unterstützt Überlegungen zur Nutzung von Drohnenbrut als Falle für die Milben (Ruttner et al, 1980; Schulz et al, 1983; Rosenkranz und Engels, 1985).

\section{Apis mellifera carnica / Varroa jacobso- ni / Drohnenbrut / Bevorzugung}

\section{REFERENCES}

Fuchs S (1985) Untersuchungen zur quantitativen Abschätzung des Befalls von Bienenvölkern mit Varroa jacobsoni Oud und zur Verteilung des Parasiten im Bienenvolk. Apidologie 16, 343-368

Fuchs $S$ (1989) The distribution of Varroa jacobsoni on honey bee brood combs and within brood cells as a consequence of fluctuating infestation rates. In: European Research on Varroatosis Control (Cavalloro R, ed), Balkema Rotterdam, 73-76

Grobov OF (1977) Varroatosis in bees. In: Varroatosis, A Honeybee Disease, Apimondia Publishing House, Bukarest, 46-70

Issa MRC, Gonçalves L (1984) Study on the preference of the acarid Varroa jacobsoni for drones of Africanized honey bees. In: $A d$ vances in Invertebrate Reproduction (Engels W, ed), Elsevier Amsterdam, NY, Oxford 3, 598

de Jong D, Morse R (1988) Utilisation of raised brood cells of the honey bee, $A$ mellifera ( $\mathrm{Hy}$ menoptera: apidae), by the Bee mite, Varroa jacobsoni (Acarina: hymenoptera). Entomol Gen 14, 103-106

Message D, Gonçalves L (1983) Einfluß der Zelldimensionen auf den Befallsgrad mit Varroa jacobsoni. Proceedings XXIXth Int Apic Congr Apimondia 1983. Apimondia, Bucharest, 276 
Maul V (1984) Empfehlungen zu Vorsorgemaßnahmen gegen Varroaschäden im Sommer 1984. I. Beurteilung der Befallsstärken und des Schadensrisikos nach dem Ergebnis der Herbstbehandlung 1983. 'Die Biene 6, 249-253

Otten C (1986) Beeinflussung des Wahlverhaltens der ektoparasitischen Milbe Varroa jacobsoni Oud. zwischen der Reproduktion in Arbeiterinnenzellen und Drohnenzellen ihres Wirtes A mellifera L. MA Thesis, Department of Biologie, JW Goethe-Universität Frankfurt/ Main

Otten C, Fuchs S (1989) Individual differences in Varroa jacobsoni of preference for drone larvae to worker bee larvae. In: European Research on Varroatosis Control (Cavalloro R, ed), Balkema Rotterdam, 69-71

Rosenkranz P, Engels W (1985) Konsequente Drohnenbrutentnahme, eine wirksame biotechnische Maßnahme zur Minderung von Varroatose-Schäden an Bienenvölkern. Allg Dtsche Imkerztg 19, 265-271

Rosenkranz P, Tewarson NC, Engels W (1984) Optimal host selection by reproductive female Varroa jacobsoni. In: Advances in Invertebrate Reproduction (Engels W, ed), Elsevier Amsterdam, NY, Oxford, 3, 628

de Ruijter A (1986) Preference of Varroa jacobsoni for different cell types and some factors affecting reproduction. Proc XXXth Int Apic Congr Nagoya, 1985. Apimondia, Tokyo, 165-167

de Ruijter A, Calis $J$ (1988) Distribution of Varroa jacobsoni female mites in honey bee worker brood cells of normal and manipulated depth (Acarina: varroidae). Entomol Gen 14, 107-109

Ruttner F, Koeniger N, Ritter W (1980) Brutstop und Brutentnahme. Allg Dtsche Imkerztg 14, 159-160

Schulz A (1984) Reproduktion und Populationsentwicklung der parasitischen Milbe Varroa jacobsoni Oud. in Abhängigkeit vom Brutzyklus ihres Wirts Apis mellifera L. Apidologie 15(4), 401-420

Schulz A, Koeniger N, Ruttner F (1983) Drohnenbrut als Varroafalle. Allg Dtsche Imkerztg $17,52-54$

Smirnov AM (1979) Aktuelle Ergebnisse der sowjetischen Wissenschaft über Ätiologie, Diagnose und Bekämpfung der Varroatose. Bekämpfung und Vorbeugung der Varroatose, Apimondia-Verlag, Bukarest, 60-74

Sulimanovic D, Ruttner F, Pechhacker H (1982) Studies on the biology of reproduction in Varroa jacobsoni. (in Japanese) Honeybee Sci 3 (3), 109-112 